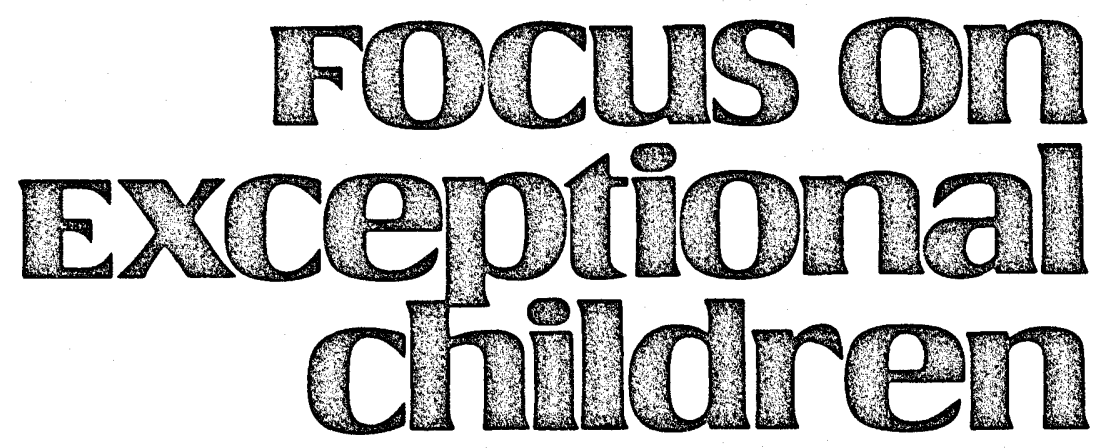

\title{
Whole Language and Learners with Mild Handicaps
}

\author{
Carol E. Westby
}

Schools are undergoing a number of paradigm shifts affecting school structure, student populations, and curriculum philosophies. The whole language approach to literacy is one of these-in this case, a shift from a basal skills approach to a literature-based language approach. A paradigm is a set of beliefs for viewing the world (Kuhn, 1970). Paradigms affect our decisions by influencing our perceptions and interpretations. A paradigm can be a magnifying lens that enables us to focus on relevant information.

The skills-based paradigm tells us that literacy is made up of a number of skills, such as decoding and identifying main ideas. The skills can be taught in isolation, and when they are all mastered, the student is literate. The whole language paradigm, in contrast, says that language should not be fragmented into skills. Language, including literacy, is learned by using language to accomplish goals in meaningful contexts (Froese, 1990).

Whole language is not a set of techniques but, rather, a philosophical and theoretical approach to education. A whole language approach to literacy involves more than reading children's literature, discussing books, writing stories, and corresponding with authors. These activities in and of themselves do not promote learning. Educators must translate the whole language philosophy and theory into a pedagogy or teaching strategies. They must consider both the content that is taught and the manner in which it is taught in terms of the specific social and cultural circumstances of students, their families, and their communities (Bloome, Harris, \& Ludlum, 1991; Sawyer, 1991).

For maximum effectiveness, a whole language approach requires thorough understanding of language development-particularly for students with language learning difficulties. During the last half of the 20th century, we have witnessed paradigm shifts in our understanding of the components of language development and the nature of language learning disabilities. The language development paradigm has shifted from attention to vocabulary and articulation development in the 1950s, to sentence structure (syntax) in the 1960s, to meaning (semantics) in the 1970s, to language use (pragmatics) in the 1980s, and to discourse in the 1990s. The current paradigm shifts in educational and clinical settings are more encompassing than the previous ones in our approaches to language development. Our paradigms are changing in a number of ways:

Carol E. Westby is a speech-language pathologist with the University Affiliated Program at the University of New Mexico, Albuquerque. 
1. Changes in language testing: From discrete point, decontextualized, standardized language testing to integrative, descriptive, naturalistic language assessment. Progress is no longer measured solely on the basis of test scores. Portfolios of children's work provide measures of language change. This shift in the testing paradigm is related to shifts in attitudes about what language learning is and is not. Language consists of more than the sum of its parts. Oral language involves more than the ability to comprehend and produce individual-elements of phonology, syntax, and pragmatics; literate language involves more than the ability to decode. Mastering these parts does not assure students' ability to integrate them into meaningful communication.

Standardized tests permit comparison of the performance of individual or groups of students on some set of selected tasks. They can predict which students may be at risk for academic difficulties. They do not, however, tell us why a student is at risk, and they do not tell us about a student's abilities in naturalistic contexts.

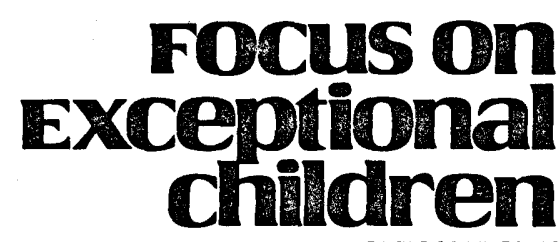

ISSN 0015-511X FOCUS ON EXCEPTIONAL CHILDREN (USPS 203-360) is published monthly except June, July, and August as a service to teachers, special educators, curriculum specialists, administrators, and those concerned with the special education of exceptional children. This publication is annotated and indexed by the ERIC Clearinghouse on Handicapped and Gifted Children for publication in the monthly Current Index to Journals in Education (CIJE) and the quarterly index, Exceptional Children Education Resources (ECER). It is also available in microfilm from Xerox University Microfilms, Ann Arbor, MI. Subscription rates: Individual, $\$ 27$ per year; institutions, $\$ 36$ per year. Copyright (C) 1992, Love Publishing Company. All rights reserved. Reproduction in whole or part without written permission is prohibited. Printed in the United States of America. Second class postage is paid at Denver, Colorado. POSTMASTER: Send address changes to:

$$
\begin{aligned}
& \text { Love Publishing Company } \\
& \text { Executive and Editorial Office } \\
& 1777 \text { South Bellaire Street } \\
& \text { Denver, Colorado } 80222 \\
& \text { Telephone (303) 757-2579 }
\end{aligned}
$$

Edward L. Meyen

University of Kansas

University of Kansas Medical Center
Stanley F. Love

Publisher
Glenn A. Vergason Georgia State University
Richard J. Whelan
ity of Kansas Medical

Holly T. Rumpler Senior Editor
To obtain information for appropriate programming in language and literacy areas, we are beginning to use authentic, ecologically valid assessments that present language or literacy tasks in ways in which language is used in the home or school (Garcia \& Pearson, 1991). In authentic, ecological assessment, students talk to get needs met and to get things done, not to repeat what a teacher has said; they write to communicate a message, not to copy letters or words; they read for enjoyment and to gather information on an interesting topic, not to answer the questions in a workbook.

2. Changes in persons served: From student-centered to social systems intervention for the language-learning disabled student. The student is no longer the sole focus of assessment and treatment. Schools traditionally have located disorders or disabilities within the individual student and have not involved families in program planning. Increasing attention is being given to the role of students within their social systems-their schools, families, and communities. In some situations, the social system, not factors within the student, may be what creates the disorder (McDermott, 1974).

The social systems paradigm requires an understanding of how students function with others in their environments. How do students' families, communities, and schools support or inhibit their performance? How do these systems vary among cultural and socioeconomic groups? How can these systems be used to facilitate a student's performance? Intervention may involve not only direct work with the identified student but also with others who relate to the student-teachers, parents, siblings. Families increasingly are being incorporated into school programs.

3. Changes in our understanding of the relationship of oral and written language: From separation of oral and written language to integration. The new paradigm views reading and writing as a natural part of normal language development for all children (Fillion \& Brause, 1987). In the past, written language was viewed as developing after oral language. Oral language was thought to contribute to written language development, but written language was not viewed as contributing to oral language development. More recently, researchers have demonstrated an interdependence between oral and written language: Oral language nourishes students' literate abilities, and literate language influences oral language abilities (Kroll \& Vann, 1981).

4. Changes in service delivery: From service provision along discipline lines to collaborative consultation. The roles and relationships between teachers and speech- 
language pathologists are changing for a number of reasons. We are aware that the school curriculum is a language curriculum; we have a better understanding of the relationship between oral language and literacy; and we place more emphasis on the regular education initiative and full inclusion of special education students in the regular classroom. As a result, speech-language pathologists are becoming collaborative consultants with teachers, and jointly planning and conducting lessons within the classroom environment.

5. Changes in demographics: From a focus on student similarity to an awareness of student diversity. The population of the 1990s is not the population of the 1960s. By the beginning of the 21 st century, one third of the U.S. population will consist of minority groups, many from nonEnglish speaking backgrounds. Culturally-linguistically different students often are unfamiliar with the interaction patterns required by traditional lessons. Teacher styles that work with one segment of the population may not work with another (Bloome, Harris, \& Ludlum, 1991). Part of what children learn in school is how to "do school." They learn how to act like a student, think like a student, and talk like a student. To access literacy learning, students first must learn how to do school.

When teaching culturally-linguistically different students, educators have to understand not only the content to be learned but also the ways in which the content could be taught. Delpit (1988) and de la Reyes (1991) have suggested that whole language approaches (as they are currently implemented) may not be particularly effective with Black and Hispanic students because the students are not used to or comfortable with the participant structures used in the whole language approach.

6. Changes in teacher roles: From teachers as transmitters of knowledge to teachers as facilitators of learning. Traditionally, teachers determined the content to be taught, presented the content, and expected students to reproduce the material. In whole language approaches, learning is viewed as a process, not simply a product. The way in which students acquire and use the information is as important as, if not more important than, the information itself. What is taught to a given student depends on the teacher's perceptions of that student's present skills and the skills the student needs to understand the task.

Children acquire language through immersion in a language-rich environment. The teacher as facilitator assists students in this learning by providing models through per- sonal communication and by listening and responding to students' communication attempts.

7. Changes in the role of students: From passive-learning students to active-learning students. Whole language programs view students as active learners who are given the opportunity to construct understanding of situations and events by selecting and organizing experiences. Rather than simply memorizing material, students plan and participate in field trips, hands-on art and science projects, and discussion of the activities and projects with their peers.

These seven paradigm shifts undergird the whole language movement. The whole language philosophy translates to an attempt to apply the transactional process observed in oral language learning to the process of literacy acquisition. To accomplish this, teachers must learn to be effective observers of individual students and sophisticated interpreters of their communication efforts. Educators also must understand the nature of language learning. They must recognize children's current skills and decide on ways to interact that will facilitate children's language development.

The tendency in whole language programs has been to assume that direct instruction is inappropriate and that simply providing interesting, motivating experiences will be sufficient. That approach probably will not be effective with learning disabled students. If it were sufficient, these students would not be exhibiting language learning delays or disorders. Students with mild handicaps can benefit greatly from whole language programs, but only if teachers are alert to the students' current language learning abilities and their language learning needs with respect to the curriculum.

Instruction in whole language classrooms for learners with mild handicaps (or any learner, for that matter) should be consistent with what Vygotsky (1978) described as the child's zone of proximal development. What should be taught, to whom, and when depend on teachers' and language specialists' perceptions of students' present language abilities and the abilities they need to accomplish certain tasks (Tharp \& Gallimore, 1988). The teacher begins with activities that students cannot do alone but can do with assistance. The teacher models the process and scaffolds the task so the students can gradually take more and more of the responsibility of carrying out the task.

Compared to language during preschool years, language during the school years requires an increased variety of language functions, greater variety of discourse 
styles and organization, more abstract vocabulary, more complex syntax, and the ability to reflect on all these aspects of language.

\section{ORAL LANGUAGE ABILITIES IN WHOLE LANGUAGE}

In the 1990s, literacy involves more than being able to read printed words. Although the media proclaim the high illiteracy rate in the United States, more people than ever before are able to read print. The problem is not one of being able to read print but, rather, in being able to comprehend and think about what is read. The demand for increasing literacy skills is not a demand for more people to be able to read words; it is a demand for greater language skills in the service of thought. A whole language curriculum should seek to develop critical thinking skills, not simply the ability to read and write.

Whole language programs generally assume that students possess skill in oral language. This cannot be assumed for students with mild handicaps or disabilities in language learning. For these students, a whole language program must include development of oral language and thinking skills along with written language.

\section{Language Genres}

Whole language programs require that students communicate to their peers and the teacher. They must share ideas and interpretations about the activities they participate in and the books they listen to and read. To do so requires children to have an adequate command of the phonology, syntax, semantics, and pragmatics of oral language. They must be able to communicate a message that is intelligible, syntactically understandable, clear in meaning, and appropriate to the situation. These messages may be organized in different ways, called genres. Whole language programs must recognize that there is not just one way for children to communicate; there is not one type of conversation, one type of reading, or one type of writing. Each genre uses distinct vocabulary and syntactic structures (Black, 1985; Grabe, 1987; Graesser \& Goodman, 1985; Kieras, 1985).

\section{Narrative Genres}

Narrative language is particularly important for success in the early school years. Most texts used in kindergarten through third grade are in a narrative format. There are a variety of narrative types (Heath, 1986a; 1986b). In addi- tion to exposing students to fictional and biographical stories, teachers in whole language classrooms should provide opportunities for students to produce a variety of narrative genres such as:

1. Recounts. An adult requests that a child talk about something the adult and the child have shared. For example, the teacher says, "Tell Ms. Lopez (the librarian) about our visit to the zoo yesterday" or "Tell me what we discussed in history class." Adults can support children's recounting by asking "scaffolding" questions: "What did the gorilla do? What did you do when the bird landed on you? Who rode the camel?" The scaffolding questions adults ask guide students in the type of information they should include so they eventually can relate information without this assistance.

2. Eventcasts. Eventcasting is talking about what one is doing as one is doing it; it is talking aloud to oneself. Eventcasting has been related to segmentation abilities and the development of self-regulatory speech. In eventcasting, children learn how to break behavior into its elements. Eventually, children learn how to segment sentences into words and words into phonemes. Older children and adults may eventcast to help them manage difficult tasks, for example: "What do I have to do today? Let's see. . . . I need to study for tomorrow's test, then work on my math assignment." Teachers can model eventcasting as they do the daily classroom activities: "I'm looking for my roll book. It's not under these papers. I'll look on the shelf. ..." They can encourage children to eventcast (talk aloud) as they work on tasks: "I'm putting a puzzle together. I'm looking for a red piece." If children have difficulty talking aloud at first, teachers can eventcast for them: "You have a blue piece. You're fitting it into Miss Piggy's dress. It fits."

3. Accounts. Accounts are narratives about a personal experience a speaker offers to listeners who are unfamiliar with the experience. For example, a child may have gone camping with her parents on the weekend. On Monday she excitedly tells her teacher, who was not on the outing, about her experiences. Because the teacher did not participate in the experience, he cannot provide the type of scaffolding support he does for recounts. The child must organize the account with little or no assistance from listeners.

Teachers can provide opportunities for students to practice accounting. "Sharing time" is one frequently used activity. Accounting is often quite difficult for students with mild handicaps because they must talk about something 
that is not present, keep the topic in mind, sequence the information, and consider the listener's perspective. Teachers can design some ways to facilitate accounting. They can encourage parents to send notes or call them about special experiences the child has had so they will be able to encourage an account and have some knowledge about it. Teachers can select topics for accounting, such as a time I got scared, inviting a friend home, my birthday party, that everyone would likely have experienced. They can model talking about the topic. Students can be encouraged to join in with their experiences. In choosing a topic that everyone can talk about, modeling and asking scaffolding questions become easier and students can hear how others organize information about experiences similar to their own.

Schools rely heavily on stories, recounts, and eventcasts. Textbooks in the early grades usually are in story format. In most testing situations, students are expected to recount something that has been taught. In science, art, and activity-based language programs, children are expected to produce a running eventcast of their activities. Opportunities for accounts occur less frequently in the academic school environment than at home or on the playground. Because accounts commonly are used to initiate and precipitate social interactions, however, students should be able to give accounts.

\section{Expository Genres}

By mid-elementary school, students must master expository texts that require greater abstraction and generalization than narratives do. They must be able to discuss not only one experience of a vacation (a narrative) but also the characteristics of vacations in general (an exposition). They must be able to talk about not only their dog at home (a narrative) but also about dogs in general and dogs in relationship to other animals (exposition). They must master a variety of expository genres, such as the descriptive genre that describes types of dinosaurs, the comparisoncontrast genre that compares plant-eating with meat-eating dinosaurs, the cause-effect genre that explains causes of the dinosaurs' extinction, the sequential-procedural genre that describes the steps in preparing dinosaur bones for exhibit, or the problem-solution genre that presents the problem of animals nearing extinction and what can be done to prevent their extinction.

A whole language program must expose students to a range of language genres. The focus of many whole language programs has been on high quality children's litera-

ture, primarily fictional literature. The ability to comprehend and produce fictional narrative texts does not assure the ability to comprehend the variety of expository genres. Teachers should make a point of exposing students to activities and texts that require a variety of expository genres. Teachers in whole language programs can prepare students for expository text by requiring the use of expository genres in familiar contexts as well as in printed texts. For example:

Sequential-procedural genre:

Cause-effect genre:

Problem-solution genre:

\section{Language and Thought}

The narrative and expository language genres of school require children to use language for increasingly abstract functions. The early language functions of young children are focused on meeting immediate needs. Children request objects they want or command people to do things for them (up, come, out, help), or they show objects they have. They talk about only what they see in the environment. Their language is tied to their perceptions. Eventually they talk about people and events they saw in the past or that they will see in the future, and later still they talk about ideas they cannot see at all.

\section{Language Functions}

The ability to use language for other than purposes of meeting needs is critical for the academic tasks schools require. In addition, children must use language to direct (including monitoring their own and others' behavior), to report, to predict, to project into thoughts and feelings of others, and to reason (Tough, 1979). Further, they must be able to use all of these functions in creating imaginary scenes in play and storytelling. Pretend play actually provides an ideal environment for using all of these language functions.

For example, a special education classroom teacher set up a McDonald's play area in her room. She programmed the classroom computer with the McDonald's menu, and 
she provided pretend food items and boxes, napkins, and paper cups donated by a local McDonald's restaurant. While participating in the play, she modeled the various language functions:

Requesting:

Directing:

Reporting:

Predicting:

Projecting into others' thoughts and feelings:

Reasoning:
"I'd like a hamburger and a chocolate shake."

"I'll get more bags."

"Please enter Michelle's order on the computer."

"I put pickles, onion, lettuce, and tomato on your hamburger." "I burned myself with the grease from the french fries."
"There are lots of people here.
I think we'll have to wait a
long time."
"She's in a hurry."
"She's mad because you didn't give her the right change."
"I don't have enough money, so I'll have to borrow some." "I can't find a place to sit because there are so many people."

The teacher observed that the children talked more and used language more for predicting, projecting, and reasoning when they were dealing with familiar themes in play than when they were talking about stories or other academic activities. As she encouraged more use of a variety of language functions in play, however, she was able to refer to these functions when discussing the behaviors, thoughts, and feelings of characters in stories.

\section{Language-Thinking Hierarchy}

Bloom (1956) recommended a hierarchy of languagethinking levels that should be part of a school curriculum. No ages were attached to these levels because, even in the elementary school, all levels may be required depending on the content of the course and the expectations of teachers. Each level requires the information and skills of the previous level. Students must be able to show they recognize and comprehend information, and they must be able to analyze, synthesize, and evaluate the information.

Table 1 explains each level and gives examples of ques- tions asked in an elementary special education classroom. The questions in the science activity initially might seem quite difficult. The children, however, had had considerable firsthand experiences with geology. They lived in Albuquerque, New Mexico and had visited the mountains on the east side of the city and picked up pieces of granite rock containing fossils and rose quartz. They traveled around the mountains to visit an old coal mine. They went to the west mesa, walked down into an extinct volcano, and picked up pieces of basalt, obsidian, and pumice. Their teacher read the book, The Magic School Bus Inside the Earth (Cole, 1987). (This book describes a field trip in which children journey in a magical bus to see how rocks are formed inside the earth.) In the classroom they constructed papier maché volcanos and used vinegar and soda to make them erupt. They collected rocks. They wrote about all their experiences.

\section{Oral Interactive Discourse}

The activities involving these various genres and levels of thought require students to talk with one another and with teachers. Oral interactive discourse is not new to school-age children. The rules and the structure of these interactions, however, may change in school. In school, students are expected to participate in class discussions and work cooperatively in groups. Children must become more sensitive to their listeners, and they must know how to manage conversations. They must be able to get a turn in a conversation, initiate topics, maintain topics, give turns to others, respond to requests for conversational repair, and request repairs from others (Brinton \& Fujiki, 1989; Donahue, Pearl, \& Bryan, 1983; Fey \& Leonard, 1983; Schneider, 1982). Deficits in oral interaction skills prevent students with language-learning disabilities from effectively participating in classroom discussions and group projects.

The accounting (sharing time) activity mentioned earlier provides many opportunities for conversational management. Students' comments should be related to the topic in some way. If there is no apparent relationship, the teacher might say, "We're talking about scary experiences. Are you talking about a scary experience?" The teacher may make explicit the rules for getting a turn in a conversation: "Wait until Brian has finished" or, "Look at the person talking so she'll know you're interested and may want a turn to talk." When she is unclear about what a student has said, the teacher may question with "What?" or requests for clarification: "Could you tell me more? Where did you say it hap- 
Table 1

\section{Sample Questions Using Bloom's Taxonomy}

\begin{tabular}{|c|c|c|}
\hline Level & Definition & Language Arts Examples \\
\hline Knowledge & $\begin{array}{l}\text { Memorizes and repeats infor- } \\
\text { mation presented; answers } \\
\text { simple questions. }\end{array}$ & $\begin{array}{l}\text { What was the little girl's name } \\
\text { in Charlotte's Web? Where } \\
\text { did Templeton the rat live? }\end{array}$ \\
\hline Comprehension & $\begin{array}{l}\text { Demonstrates understanding } \\
\text { by paraphrasing or stating in } \\
\text { another form. }\end{array}$ & $\begin{array}{l}\text { What was the story about? } \\
\text { Tell me the story you just } \\
\text { heard. }\end{array}$ \\
\hline Application & $\begin{array}{l}\text { Uses information, rules, meth- } \\
\text { ods, or principles in new but } \\
\text { similar situations. }\end{array}$ & $\begin{array}{l}\text { Charlotte and Wilbur are } \\
\text { friends. How can friends help } \\
\text { each other? }\end{array}$ \\
\hline Analysis & $\begin{array}{l}\text { Identifies components, gives } \\
\text { reasons, identifies problems. }\end{array}$ & $\begin{array}{l}\text { How did Wilbur change over } \\
\text { the course of the story? }\end{array}$ \\
\hline Synthesis & $\begin{array}{l}\text { Abstracts from previously } \\
\text { learned knowledge to gen- } \\
\text { erate new solutions to } \\
\text { problems. }\end{array}$ & $\begin{array}{l}\text { What would have happened if } \\
\text { Templeton hadn't found } \\
\text { words for Charlotte to weave } \\
\text { in her web? }\end{array}$ \\
\hline Evaluation & $\begin{array}{l}\text { Compares alternatives, states } \\
\text { opinions, justifies responses. }\end{array}$ & $\begin{array}{l}\text { Which character do you like } \\
\text { best in the story, and why? }\end{array}$ \\
\hline
\end{tabular}

\section{Science Examples}

What kind of rock is made of mud and clay pressed together?

\section{Explain how metamorphic rock is produced.}

(after a discussion of the characteristics of granite) What could we use granite for?

How are limestone, shale, and sandstone alike?

How would the world be different if there were no volcanos?

If you were commissioned to create a monument, what type of rock would you use, and why?

pened?" When children are talking, the teacher may suggest clarifying questions that one child might ask another: "Jim, ask Andrew who else was at his birthday party."

\section{LITERATE KNOWLEDGE FOR WHOLE LANGUAGE LEARNING}

Students must bring their oral language skills to bear when reading and writing. Comprehension and production of texts requires that students use their pragmatic, semantic, syntactic, and phonological skills in more complex ways. Students also must have the language skills and knowledge to succeed with academic tasks. They must have a literate language style, schemas for content information, knowledge of text structures, metalinguistic skills, and metacognitive monitoring abilities (Lesgold \& Perfetti, 1981; Marzano, Hagerty, Valencia, \& DiStefano, 1987).

Schools use a more formal literate language style than the oral interactive language of the home or playground (Westby, 1984; 1985). Written language is not simply oral language written down. Written language uses more explicit vocabulary and complex syntax. Semantic information must be integrated into larger units or content schemas. Students must understand relationships among semantic elements. For example, not only must they understand what a spider is-its characteristics-but also what it does, where it lives, its relationship to other arachnids, its relationship to insects, the relationship of arachnids and insects to other animals, and so on. The information in these content schemas is presented in systematically organized patterns called text structures or text grammars (Anderson \& Pearson, 1984; Meyer \& Rice, 1984).

Reading and writing require metalinguistic abilities, or conscious awareness of language. Students must be able to separate words from the speech stream, segment words into sounds, and match phonemic sounds with grapheme symbols (Clay, 1975; Temple, Nathan, Burris, \& Temple, 1988). Students must use metacognitive monitoring abilities to determine if they are comprehending oral and written information. They must use metacognitive strategies when they have failed to comprehend and when they are presented with complex learning tasks (Baker \& Brown, 1984). 
A strength in one knowledge area may compensate for a weakness in another area. For example, a student with weak metalinguistic skills may be able to use content knowledge to predict words; a student weak in content schemas may use metacognitive strategies to gain additional schema knowledge. All these aspects of literate language must be addressed in whole language programs for learning disabled, mildly handicapped students.

\section{Literate Language Style}

Reading and writing require a language style that differs from oral-interactive language in vocabulary, syntax, and organization. In an oral style, speakers may use nonspecific language (pronouns and words such as that, this, here, there, stuff, things) and short sentences. Ideas may be strung together in an associative style, with one idea leading to another but with little or no relationship among all the ideas. In the literate style, speakers and writers must use explicit vocabulary, complex syntax, and a topic-centered style that makes specific the interrelationships between elements of the text. When an adult and a child are looking at a picture in a book together, they understand if one says:

He hit him. He ran away.

Without the context of the picture, however, these sentences make no sense. One does not know who did the hitting, who ran away, and why he ran. To understand what happened when no pictures are available, one may need to say or write:

The boy who stole the bike hit the boy who was watching. Then the boy who saw the bike being stolen swiftly ran away because he was not strong enough to fight back.

In addition to the conjunctions and, then, and because used in oral conversation, literate language uses conjunctions such as but, therefore, however, meanwhile, nevertheless, in addition, adverbs (swiftly, angrily, smoothly), adverbial phrases (when I finish my homework), and relative clauses (The clever fox, who tricked the coyote into holding up the mesa, trotted off with the money).

Students with learning disabilities and mild handicaps frequently are exposed to less complex language. They may read "high interest, low vocabulary" books that use only familiar words and that simplify syntax by avoiding compound and complex sentences. Students acquire liter- ate-style language only by exposure. Students with mild handicaps are capable of acquiring the literate language style when they have interesting, meaningful texts. Cumulative and predictive books provide a means of exposing them to complex vocabulary or syntax in ways they will remember and comprehend. For example, in the familiar story Millions of Cats, Gag (1928) repeatedly described the man's predicament in choosing a cat, using complex sentences with conjunctions and relative clauses:

But then he saw a fuzzy grey kitten way over here which was every bit as pretty as the others so he took it too.

\section{Content Schema}

A content schema refers to organization of knowledge about a given topic or domain. Content schemas include semantic knowledge as well as cognitive knowledge of spatial, temporal, and causal relationships. One can have schemas for scenes (houses, jungles, schools), events (birthday parties, camping trips), and concepts/ideas (government, energy). A schema for a school might consist of classrooms, chalkboards, desks, chairs, books, teachers, principal, gym, restrooms. A schema for a birthday party could include the person having the birthday, gifts, ice cream, cake, playing games, blowing out candles, singing happy birthday. Event schemas also might include the scripts, or what people engaging in the event would say. A schema for energy could include sources of energy, location of energy sources, how energy is produced, pollution created by energy generation, and so on.

Schema content can be developed by teaching in thematic units. Rather than reading one book on a topic, or discussing a concept or theme in only one class, whole language teachers present the theme in multiple ways throughout the day. For example, an elementary special education class did a unit on bears. The students listened to a variety of stories about bears and read several versions of The Three Bears, including a classic by Galdone (1973), a Hawaiian version, Wili Wai Kula and the Three Mongooses (Laird, 1983), and a wordless picture book, Deep in the Forest (Turkle, 1976), in which a bear visits the peoples' house. They read stories about real bears, such as Blueberries for Sal (McCloskey, 1948). They read stories about cartoon bears, such as The Berenstain Bears and the Messy Room (Berenstain \& Berenstain, 1983). They read stories about teddy bears, such as A Pocket for Corduroy (Freeman, 1978) and The Night After Christmas (Stevenson, 1981). And, of course, they read Winnie the Pooh (Milne, 1926). 
The students compared and contrasted the bears in the stories. In math class they used colored counting bears of different sizes. In science class they discussed where bears lived and what bears needed to eat. That fall, because of a particularly dry summer, 21 bears came down from the mountains into Albuquerque looking for food. Students talked about why the bears had to be captured and relocated. They planned a teddy bears' picnic. The children brought their own teddy bears from home, and they served foods bears might like (e.g., blueberries, honey), although they rejected some foods bears might like (such as bugs and raw fish). At the picnic they played Blind Bear's Bluff. Before being blindfolded, the children looked carefully at all the bears. Then they felt a bear, used words to describe the bear, and guessed who owned the bear.

Teachers also can assess and facilitate students' content knowledge by engaging them in semantic webbing activities surrounding a topic or theme. Words or themes can be selected from the students' textbooks. The teacher writes the word or theme on the chalkboard and asks students to generate ideas related to the word or theme. As the students give suggestions, the teacher requests information regarding the relationships among the words and ideas they suggest. Children who are able to develop extensive webs for a topic are more likely to be able to follow a topic of conversation or a theme in a text.

\section{Text Grammars}

The content of texts is organized or structured systematically. This structure is called a text grammar. Students who are able to recognize text structures show better comprehension (Fitzgerald, 1989; Slater \& Graves, 1989).

\section{Components and Assessment of Structure}

All narratives in Western cultures involve the same basic structure, which consists of:

Setting:

Initiating event: A natural occurrence (e.g., earthquake, tornado), an activity of a character (e.g., stealing, threat), the perception of an event (hearing thunder), or changes in physiological state (hunger, pain), which triggers a response in characters.
Internal response: The emotional state of the character in response to the initiating event.

Plan:

A character's strategy for obtaining a goal.

Attempt: $\quad$ A series of actions the character intentionally carries out in an effort to achieve a goal.

Consequence: The success or failure of the character in achieving a goal.

Resolution: The character's feelings, thoughts, or actions in response to the consequences of attaining or not attaining a goal.

Ending: $\quad$ A statement announcing the conclusion of the story, summarizing the story, or stating a moral or general principle.

By third to fourth grade, students are expected to be able to comprehend and produce a complete narrative episode that includes all these elements. If students do not recognize and understand these elements of stories, they will have difficulty in comprehending many of the books used in whole language literacy programs. Students' knowledge of the temporal and physical and psychological cause-effect relationships reflected in stories can easily be assessed by asking them to relate a story in wordless picture books. Many of the books by Mercer Mayer-for example, One Frog Too Many (1975), A Boy, A Dog, and A Frog (1967), Frog Goes to Dinner (1974), A Boy, A Dog, A Frog, and A Friend (1971)-are particularly useful for this purpose because they include all the elements of complete or complex episodes. The student is told, "Tell me the story that happened in this book. Make it the best story you can." If the student is hesitant to tell the story or has trouble organizing extended verbal responses, the examiner can ask questions that focus on the relationships:

Reporting: "What was the boy doing here? What happened here? Tell me about this picture."

Projecting: "What is the boy saying to the big frog? What is the frog thinking? How does the boy feel?" 
Reasoning:

"Why is the frog thinking that? Why did the tree fall down?"

Predicting:

"What will happen next?

What will the big frog do now?"

Teachers can evaluate the students' performance by considering the following questions:

1. Does the student simply label/describe pictures, or does she interpret the picture? That is, does the child use information in the pictures to generate schemas that go beyond the details of the pictures? For example, if a picture shows a boy carrying a pole, a bucket, and a net, does the student simply say, "The boy has a pole, and a bucket, and a net" or does she infer, "The boy is going fishing"?

2. Does the student indicate awareness of temporal relationships in stories? Does the child use temporal markers or conjunctions that indicate time relationships? (These include just, already, always, before, after, while, then, when, now, as soon as.)

3. Does the child recognize the characters' emotional feelings? What words does she use to describe the feelings?

4. Does the child explain relationships between characters' emotions and events in the story by using words such as because, so, therefore?

5. Does the child recognize the theme or reason for the characters' goal-directed behaviors? Does the child explicitly state the story theme?

The teacher can assess students' ability to integrate narrative relationships into an organized narrative structure by asking them to tell a story about a poster picture. Table 2 describes the developmental stages of storytelling and gives example stories for each level.

Students with learning disabilities and mild handicaps generally exhibit significant delays and disorders in narrative abilities. They may not understand the story content or relationships that underlie stories, and/or they may not be able to organize information into a cohesive and coherent story. To assure students' comprehension of narratives when reading stories, teachers have to be aware of a student's current narrative abilities. The teacher may want to select stories that will highlight specific aspects of story structure. For example, if a child produces a series of unrelated or temporally related actions, the teacher may want to introduce cause-effect relationships by presenting sto- ries that make cause-effects explicit. For example, he may read Round Robin (Kent, 1982), the story of a robin who eats so much in the summer that when winter comes, it is too fat to fly south. Or he may read some of the pour quoi tales from other cultures that explain why things are as they are. For example, Why the Sun and Moon Live in the Sky (Dayrell, 1968) explains that sun and moon had to leave their house because when water came to visit, he overflowed the furniture, room, and house until the only place for them was in the sky.

\section{Expository Text Grammars}

Expository texts have more variety in structures than narrative texts do because the former are about a greater variety of ideas. Not only do different texts have different structures, but any text may also have several different structures. To comprehend expository texts, students must acquire a variety of text structures and be able to switch between these structures within a single text. Recognizing and comprehending key words that signal the various text structures and relationships among the text elements is an essential skill for reading and writing expository texts. Table 3 presents the major types of expository texts, their functions, and key words that signal the type of expository text. To comprehend expository texts, students must comprehend these words, recognize that these words signal text organization, and then use knowledge of these structures to recognize the relationship among the concepts presented.

\section{Metalinguistic Skills}

The term metalinguistics refers to the ability to reflect on language or to use language to talk about language. Metalinguistic skills involve the ability to segment the sound stream into words and phonemes, to identify sound/symbol relationships, and to recognize that words and phrases can have multiple meanings.

\section{Segmentation}

Analyzing language into linguistic units is essential in learning to read. It is frequently assumed that children learn segmentation skills and sound/sound relationships simply by being exposed to print-rich environments. For many students this is true. Students with learning disabilities and mild handicaps, however, often have particular deficits in segmentation abilities and sound/symbols awareness (Kamhi, Catts, Mauer, Apel, \& Gentry, 1988). Consequently, if they are to acquire these skills, they likely will require additional direct teaching. 


\section{Table 2}

\section{Development of Stories}

\section{Content/Structure}

\section{Preschool Level}

Isolated description: Child labels or describes objects, characters, surroundings, or ongoing actions; no true sequence of actions.

Action sequence: Child lists actions that appear to be temporally sequenced; characters act independently of each other; story may have a central character or a central theme (actions that each character does).

Reaction sequence: One event or action automatically causes other events or actions, but no planning is involved.

\section{Early Elementary School}

Goal-directed episode: The story character has some goal to achieve. There may be some reference to the character's feelings. The character engages in activities to achieve the goal, but the planning to achieve the goal is not explicit; the planning must be inferred.

Complete episode: The story describes the goals and intentions of the characters, and the characters' planning to achieve the goals is made clear.

\section{Later Elementary}

Complex episode: At least one obstacle lies in the goal path (e.g., the first thing the characters try to reach a goal does not work and they must try something else).

Embedded episode: This is a story within a story. The first goal in the story is interrupted to accomplish a second goal. Then the first goal is accomplished.

\section{Sample Story}

There is a ghost and a pumpkin. The witch is a woman. She flies a broom. The witch is black. The witch chews Skol and makes cigarettes. The witch lives in California and Arizona. She does not come to Alamo.

Once there was some kids. And they were going to school. A giant bird flew over and landed. Then they got a piece of rope and put it in his mouth. The bird took off. And they had a good, good trip. They flew over the ocean, the mountain. Finally they came home.

There were two boys who went to China. And they made friends with a bird. And so they were flying around China. And they were going over a city where a statue was. But then a storm came. And the eagle's wings couldn't flap, so they crash landed in the trees.

A UFO came from outer space. Then the UFO came upon a big house. There were some scientists working in a building next to the big house. The UFO wanted to study earth people. One of the scientists was taken by the UFO and put in a big locker. Then the UFO went into a black hole and was never seen again.

For a whole month there had been a real big giant that had been throwing things in the houses and smashing houses and getting people and throwing them. But one day there was a man who wanted to solve this problem. So he got all the men. And they started up the mountain with torches to see what they can do about it. So they were about 10 feet from him. One of the men threw a torch at him and lit the giant on fire. And the giant fell down the mountain. And they never see him again.

Once upon a time there was a village in the mountains. And there was a gorilla that escaped from the zoo. And they went hunting for it. And it was on the top of a ledge. And they started chasing it with guns and swords. It run up the hill, and then it fell over the edge. And then the men tried to get it, but it jumped and it wrecked their house. And then they started chasing it up the mountain again. And he started to ski down 'cause he found a pair of skis at the top. And then the people got skis. So they chased him on skis. And they chase him right to the zoo. And he got back. He got caught in the zoo again.

A man named Mr. Dirt lived in the country all by himself and owns a farm. One calf got away and went to the woods and headed up the mountains. So Mr. Dirt went up the mountain after the calf. On the way a bear came after Mr. Dirt. He ran up a tree and the bear climbed up the tree after him. Mr. Dirt threw his ax at the bear and hit the bear in the head. Blood poured out of his head and the bear fell down and died. A few minutes later the calf ran over to Mr. Dirt. 


\section{Table 3}

\section{Expository Text Grammars}

\section{Text Pattern/Function}

Descriptive text: Tells what something is.

Collection/enumeration text: Lists things related to the topic.

Sequence/procedure text: Tells what happened or how to do something or make something.

Comparison/contrast text: Shows how two things are the same or different.

Cause/effect explanation text: Gives reasons why something happened.

Problem/solution text: States a problem and offers solutions to the problem.

\section{Key Words}

is called, can be defined as, is, can be interpreted as, is explained as, refers to, is a procedure for, is someone who, means

an example is, for instance, another, next, finally, such as, to illustrate

first, next, then, second, third, following this step, finally, subsequently, from here ... to, eventually, before, after

different, same, alike, similar, although, however, on the other hand, contrasted with, compared to, rather than, but, yet, still, instead of

because, reasons, then, therefore, for this reason, results, effects, consequently, so, in order to, thus, depends on, influences, is a function of, produces, leads to, affects, hence

a problem is, a solution is
Activities that involve rhyming and word substitutions in predictive texts can facilitate the ability to segment words from the speech stream. Children can be taught familiar rhymes and then assisted in varying them by substituting words, such as:

\section{Humpty Dumpty sat on a tack. \\ Humpty Dumpty sat on a chair. \\ Humpty Dumpty sat on a hill.}

Closely related to the ability of phonemic segmentation is the development of knowledge of sound-symbol association. Children from highly literate environments frequently acquire some awareness of sound-symbol relationships during the preschool years and will engage in spontaneous writing using invented spelling. Children match the way they produce the phonemes of the language with the way they say the letters of the alphabet. Many letters have a letter-sound match. For example, in $\mathrm{B} / b i l, \mathrm{~F} / \varepsilon f l, \mathrm{~S} / \varepsilon s /, \mathrm{L} / \varepsilon l$, the child produces the phoneme when saying the letter name. Hence, when asked to write "baby" or "soap," the child easily can produce "babe" or "sop" by relying on this letter-sound correspondence.

Many students with mild handicaps go through the same developmental sequence of writing as nonhandicapped students do if they are provided with meaningful writing activ- ities (Westby \& Costlow, 1991). Teachers can have students establish journals in which they write meaningful messages or notes to the teacher and to each other. As they master this interpersonal communicative writing, they can be encouraged to write personal stories, then fictional stories and expository texts. Initially, the focus is on communicating a message, and invented spelling is permitted and encouraged. As students deal with writing and reading for meaning, the necessary metalinguistic skills are introduced and discussed: What are words? How do you "sound out" words? What letters go with what sounds? How and why do you use punctuation?

Learners with mild handicaps, particularly some of those who have had a history of articulation problems, poor oral-tactile sensitivity, or poor auditory discrimination, may require direct teaching of sound-symbol relationships. These students should be introduced explicitly to the alphabetic principle that letters stand for sounds. They should be taught to name the letter, to give the sound of the letter, to note what they do with their lips and tongue when they say the letter or sound, and to give a word that begins with the sound. Highly structured phonetics programs, such as the Orton-Gillingham approach (Gillingham \& Stillman, 1960), are appropriate and even essential for some students. 


\section{Multiple Word Meanings and Figurative Language}

Developing multiple word meanings and figurative language is an aspect of both semantic development and metalinguistic development. Some multiple-meaning words refer to specific concrete objects or actions (e.g., lie on the river bank; put your money in the bank; bank the car on the sharp turn), as well as to figurative meanings (don't bank on it). Some multiple-meaning words refer to both physical and psychological attributes (a sharp knife and a sharp manager; a crooked nail and a crooked accountant).

Students with learning disabilities frequently understand only the physical meaning of words such as sweet, sharp, crooked, soft, hard, warm, cold, bright, or deep, yet comprehension of both the physical and psychological meanings is generally expected between 7 and 9 years of age, and by ages 9-10 students begin to be able to explain the relationship between the physical and psychological terms (Wiig, 1989). A similar pattern of development occurs with similes (her eyes sparkle like diamonds), metaphors (sunshine of my life), and idioms (raining cats and dogs).

Stories or books that play on multiple word meanings can be an amusing way to teach the concept. For example, in Amelia Bedelia (Parrish, 1963) Amelia makes many mistakes because she is unaware of multiple word meanings. When told to "draw the drapes," she makes a pencil sketch of the drapes; when told to "dress the chicken," she put pants and socks on it. In The King Who Rained (Gwynne, 1973), the child pictures her father with a small animal on his nose when he says he has a "mole" on his nose; she imagines that she will have to hold a locomotive when her sister tells her she can hold her "train" at the wedding.

\section{Metacognitive Skills}

Metacognition refers to the knowledge that learners have about their thinking and the strategies they use to monitor comprehension and production. Metacognitive thought requires a theory of mind and the development of metacognitive verbs (know, forget, remember, guess, doubt, infer, hypothesize, conclude, assume) are critical for children's learning and participation in school activities. According to Wellman (1985), the words know, forget, remember, and guess develop between ages 3 and 7 years. To carry out teachers' instructions, children must know if they understand what is expected, and they must ask questions or ask for assistance if they do not know. They must know if they have the necessary information or if they are guessing. And they must remember what they have been told to do and be aware if they have forgotten what they were told. Without this active awareness of knowing, remembering, forgetting, and guessing, children will not function independently.

Teachers can model these metacognitive words in daily activities:

"I think this is how Jennifer's aunt kneaded the bread."

"I forgot what Ms. Garcia did after she added the flour. Go ask her."

"I remember how good the bread smelled when it came out of the oven."

"I know how to make adobe bricks from clay, straw, and water."

"Good, you remembered to bring your permission slip for the trip."

If students have language deficits in the areas discussed so far, they are likely also to have metacognitive monitoring deficits, but students can have adequate skills in all other areas yet have trouble planning their behavior and oral and written productions, monitoring their comprehension, and generating and employing strategies for learning and remembering. In general, students with learning disabilities show little evidence of using effective strategies to meet task demands (Schumaker \& Deshler, 1984; Torgensen, 1977a, 1977b). Some students do not have the oral language necessary for planning behavior; others have little awareness that mental acts exist; others may have the necessary language and awareness of mental acts but are not able to generate strategies to facilitate their performance; still others may be able to generate strategies but be uncertain of when to use them.

Throughout all activities, adults should model metacognitive strategies. They should talk aloud (eventcast) as they carry out activities. As they do so, they let students hear a variety of language functions and structures, and they also let children hear what task is to be accomplished, how the adult plans to approach the task, how the adult monitors performance, and what is done about success or lack of success (Meichenbaum, 1977). For example:

Problem definition: "What do I have to do? Let's see...."

Focusing attention and direction:
"Find step one. ... Now find the piece shown in the picture. ..." 
Self-evaluating coping skills and errorcorrecting options:

A similar strategy can be used during reading. The teacher asks the students to read along silently as the teacher reads the passage aloud and notes how they are thinking through the trouble spots. Davey (1983) suggested a number of points that can be made during this comprehension monitoring:

"From the title, I think this will be about...."

Describing the pictures you are forming in information:

Developing analogies (Show how to link prior knowledge with new information in the text): points (Show how you monitor comprehension):

Demonstrating fix-up strategies (Show how you make sense of the passage):

"This doesn't make sense."

"I'd better reread this." "I'll read ahead and see if $I$ can get some more information."
Self-reinforcement: " "Good, I found that piece."

Making predictions: your head about the

Identifying confusing

ing. Students practice these aspects of language while working on group projects.

Throughout all school activities-art, science, social studies, language arts, math, gym-adults have to be alert to language functions and levels of language abstraction that students are using. They can assist students in using more diverse functions and higher levels of thought by making statements and asking questions. Literature and textbooks should be carefully selected to be within a range of the students' present comprehension abilities, yet challenging enough to facilitate language growth.

\section{REFERENCES}

Anderson, R. C., \& Pearson, P. D. (1984). A schema-theoretic view of basic processes in reading. In P. D. Pearson (Ed.), Handbook of reading research. New York: Longman.

Baker, L., \& Brown, A. L. (1984). Metacognitive skills and reading. In P. D. Pearson (Ed.), Handbook of reading research. New York: Longman.

Black, J. (1985). An exposition on understanding expository text. In B. Britton \& J. Black (Eds.), Understanding expository text. Hillsdale, NJ: Erlbaum.

Bloom, B. (1956). Taxonomy of educational objectives. Handbook 1: Cognitive domain. New York: Longman.

Bloome, D., Harris, O., \& Ludlum, D. (1991). Reading and writing as sociocultural activities: Politics and pedagogy in the classroom. Topics in Language Disorders, 11(3), 14-27.

Brinton, B., \& Fujiki, M: (1989). Conversational management with language-impaired children. Rockville, MD: Aspen.

Clay, M. (1975). What did I write? Portsmouth, NH: Heinemann.

Davey, B. (1983). Think aloud: Modeling the cognitive process of reading comprehension. Journal of Reading, 37, 104-112.

de la Reyes, M. (1991). A process approach to literacy instruction for Spanish-speaking students: In search of a best fit. In E. H. Hiebert (Ed.), Literacy for a diverse society. New York: Teachers College Press.

Delpit, L. D. (1988). The silenced dialogue: Power and pedagogy in educating other people's children. Harvard Educational Review, 58, 280-298.

Determining school-age students' language learning needs for social and academic success in whole language programs requires assessment of their oral interactive language abilities, the language functions and genres they use effectively, the style, structure, and complexity of their language patterns, their content knowledge, metalinguistic skills, and metacognitive awareness and strategies. Teachers can help a student to benefit from whole language contexts by using oral and written language that is slightly above students' present language abilities. In conversational activities, teachers should model appropriate language functions, requests for clarification, conversational repairs, literate language style, and metacognitive monitor-
Dollaghan, C., \& Miller (1986). Observational methods in the study of communicative competence. In R. L. Schiefelbusch (Ed.), Language competence: Assessment and intervention. San Diego: College Hill Press.

Donahue, M., Pearl, R., \& Bryan, T. (1983). Communicative competence in learning disabled children. In H. Bialer \& K. Gadow (Eds.), Advances in learning and behavioral disabilities (Vol. 2). Greenwich, CT: JAI Press.

Fey, M., \& Leonard, L. (1983). Pragmatic skills of children with specific language impairment. In T. M. Gallagher \& C. A. Prutting (Eds.), Pragmatic assessment and intervention issues in language. San Diego: College Hill Press.

Fillion, B., \& Brause, R. S. (1987). Research into classroom practices: What have we learned and where are we going? In J. R. Squire (Ed.), 
The dynamics of language learning. Urbana, IL: ERIC Clearing House on Reading and Communication Skills.

Fitzgerald, J. (1989). Research on stories: Implications for teachers. In K. D. Muth (Ed.), Children's comprehension of text. Newark, DE: International Reading Association.

Froese, V. (1990). Introduction to whole-language teaching and learning. In V. Froese (Ed.), Whole-language practice and theory. Boston: Allyn \& Bacon.

Garcia, G. E., \& Pearson, P. D. (1991). The role of assessment in a diverse society. In E. H. Hiebert (Ed.), Literacy for a diverse society: Perspectives, practices, and policies. New York: Teachers College Press.

Gillingham, A., \& Stillman, B. (1960). Remedial training for children with specific disability in reading, writing, and penmanship. Cambridge, MA: Educators Publishing Service.

Grabe, W. (1987). Contrastive rhetoric and text-type research. In U. Connor \& R. Kaplan (Eds.), Writing across cultures: Analysis of L2 text. Reading, MA: Addison-Wesley.

Graesser, A. C., \& Goodman, S. M. (1985). Implicit knowledge, question answering, and the representation of expository text. In B. K. Britton \& J. B. Black (Eds.), Understanding expository text. Hillsdale, NJ: Erlbaum.

Heath, S. B. (1986a). Sociocultural contexts of language development. In Beyond language. Los Angeles: California State University, Evaluation Disseminations and Assessment Center.

Heath, S. B. (1986b). Taking a cross-cultural look at narratives. Topics in language disorders, 7(1), 84-94.

Kamhi, A., Catts, H., Mauer, D., Apel, K., \& Gentry, B. (1988). Phonological and spatial processing abilities in language and reading impaired children. Journal of Hearing \& Speech Disorders, 53, 316-327.

Kieras, D. E. (1985). Thematic process in the comprehension of expository prose. In B. K. Britton \& J. B. Black (Eds.), Understanding expository text. Hillsdale, NJ: Erlbaum.

Kroll, B. M., \& Vann, R. J. (1981). Exploring speaking-writing relationships: Connections and contrasts. Urbana, IL: National Council of Teachers of English.

Kuhn, T. S. (1970). The structure of scientific revolutions. Chicago: University of Chicago Press.

Lesgold, A. M., \& Perfetti, C. A. (Eds.). (1981). Interactive processes in reading. Hillsdale, $\mathrm{NJ}$ : Erlbaum.

Marzano, R. J., Hagerty, P. J., Valencia, S. W., \& DiStefano, P. P. (1987). Reading diagnosis and instruction. Englewood Cliffs, NJ: Prentice Hall.
McDermott, R. (1974). Achieving school failure: An anthropological approach to illiteracy and social stratification. In G. D. Spindler (Ed.), Education \& Culture Process. New York: Holt, Rinehart \& Winston.

Meichenbaum, D. (1977). Cognitive-behavior modification: An integrative approach. New York: Plenum.

Meyer, B., \& Rice, G. E. (1984). The structure of text. In P. D. Pearson (Ed.), Handbook of reading research. New York: Longman.

Sawyer, D. (1991). Whole language in context: Insights into the current great debate. Topics in Language Disorders, 11(3), 1-13.

Schneider, P. (1982). Formal operations skills vs. explanation. Psycholinguistic Newsletter (Northwestern University), 8, 16-23.

Schumaker, J. B., \& Deshler, D. D. (1984). Setting demand variables: A major factor in program planning for the LD adolescent. Topics in Language Disorders, 4(2), 22-40.

Slater, W. H., \& Graves, M. F. (1989). Research on expository text: Implications for teachers. In D. K. Muth (Ed.), Children's comprehension of text. Newark, DE: International Reading Association.

Temple, C., Nathan, R., Burris, N., \& Temple, F. (1988). The beginnings of writing. Boston: Allyn \& Bacon.

Tharp, R. G., \& Gallimore, R. (1988). Rousing minds to life. Cambridge, MA: Cambridge University Press.

Torgesen, J. K. (1977a). Memorization processes in reading-disabled children. Journal of Educational Psychology, 69, 571-578.

Torgesen, J. K. (1977b). The role of nonspecific factors in the task performance of learning disabled children: A theoretical assessment. Journal of Learning Disabilities, 10, 27-34.

Tough, J. (1979). The development of meaning. New York: Wiley.

Vygotsky, L. S. (1978). Mind in society: The development of higher psychological processes. Cambridge, MA: Harvard University Press.

Wellman, H. M. (1985). The origins of metacognition. In D. L. ForrestPressley, G. E. MacKinnon, \& T. G. Waller (Eds.), Metacognition, cognition, and human performance. New York: Academic Press.

Westby, C. E. (1984). Development of narrative language abilities. In G. P. Wallach \& K. G. Butler (Eds.), Language learning disabilities in school-age children. Baltimore: Williams \& Wilkins.

Westby, C. E. (1985). From learning to talk to talking to learn: Oral-literate language differences. In C. Simon (Ed.), Communication skills and classroom success: Therapy methodologies for language-learning disabled students. San Diego: College-Hill.

Wiig, E. (1989). Steps to language competence. New York: Psychological Corp. 


\section{CHILDREN'S BOOKS}

Berenstain, S., \& Berenstain, J. The Berenstain bears and the messy room. New York: Random House.

Cole, J. (1987). The magic school bus inside the earth. New York: Scholastic Books.

Dayrell, E. (1968). Why the sun and moon live in the sky. Boston: Houghton Mifflin.

Freeman, D. (1978). A pocket for Corduroy. Cedar Grove, NJ: Puffin Books.

Gag, W. (1928). Millions of cats. New York: Coward, McCann \& Geoghegan.

Galdone, P. (1970). The three little pigs. New York: Clarion Books.

Galdone, P. (1973). The three bears. New York: Scholastic.
Gwynne, F. (1973). The king who rained. New York: Young Readers Press. Kent, J. (1982). Round robin. Englewood Cliffs, NJ: Prentice Hall.

Laird, D. (1983). Wili wai kula and the three mongooses. Honolulu: Barnaby.

Mayer, M. (1975). One frog too many. New York: Dial Press.

Mayer, M. (1967). A boy, a dog, and a frog. New York: Dial Press.

Mayer, M. (1974). Frog goes to dinner. New York: Dial Press.

Mayer, M. (1971). A boy, a dog, a frog and a friend. New York: Dial Press.

McCloskey, R. (1948). Blueberries for Sal. New York: Penguin.

Milne, A. A. (1926). Winnie-the-Pooh. New York: E. P. Dutton.

Parrish, A. (1963). Amelia Bedelia. New York: Scholastic Books.

Turkle, B. (1976). Deep in the forest. New York: E. P. Dutton.

Stevenson, J. (1981). The night after Christmas. New York: Greenwillow.

\section{PERMISSIONS AND COPYRIGHT}

All rights are reserved. No part of this publication may be reproduced, photocopied, faxed, stored in a retrieval system, or transmitted, in any form or by any means, electronic, mechanical, recording or otherwise, without the prior written permission of the publisher.
Back issues are available for sale. Reproduction requires permission and payment of fees. It is illegal and a violation of Federal copyright law to reproduce this publication without permission. Direct all inquiries to the permissions editor. 